\title{
Carbohydrate digestive enzymes are inhibited by Poincianella pluviosa stem bark extract: relevance on type 2 diabetes treatment
}

Camila Gabriel Kato-Schwartz ${ }^{1}$, Anacharis Babeto de Sá-Nakanishi ${ }^{1}$, Ana Carolina Guidi Geferson de Almeida Gonçalves', Fernanda Giacomini Bueno ${ }^{3}$, Beatriz Petroncine Martins Zani ${ }^{4}$, João Carlos Palazzo de Mello ${ }^{2}$, Paulo Sérgio Alves Bueno ${ }^{5}$, Flavio Augusto Vicente Seixas ${ }^{5^{*}}$ (D), Adelar Bracht ${ }^{1}$ and Rosane Marina Peralta ${ }^{1 *}$

\begin{abstract}
Background: The stem bark aqueous alcohol extract of Poincianella pluviosa (PPSB extract) is rich in bioactives including gallic acid, gallic acid methyl ester, pyrogallol, ellagic acid, corilagin, 1,4,6-tri-O-galloyl-glucose, 1,2,3,6-tetraO-galloyl-glucose, 1,2,3,4,6-penta-O-galloyl-glucose, tellimagrandin I, tellimagrandin II, mallotinic acid, mallotusinic acid, and geraniin. The aim of the present study was to evaluate the antioxidant activity of the PPSB extract as well as its inhibitory action on carbohydrate digestive enzymes relevant to type 2 diabetes.
\end{abstract}

Results: The PPSB extract was prepared using a mixture of $40 \%$ ethanol and $60 \%$ distilled water. The PPSB extract showed high antioxidant activities and inhibited several carbohydrate digestive enzymes. The $\mathrm{IC}_{50}$ values for inhibiting in vitro salivary amylase, pancreatic amylase, intestinal $\beta$-galactosidase and intestinal invertase were, respectively, $250 \pm 15,750 \pm 40,25 \pm 5$, and $75 \pm 8 \mu \mathrm{g} / \mathrm{mL}$. In vivo inhibition of the intestinal starch absorption was confirmed by determination of blood glucose levels in rats before and after administration of starch by gavage with or without different amounts of PPSB extract. Docking simulations performed on three different programs to rank the extract compounds most likely to bind to porcine pancreatic a-amylase suggest that geraniin is likely to be the P. pluviosa extract compound that presents the greatest binding potential to the pancreatic alpha-amylase. However, the total inhibitory action of the PPSB extract is likely to result from a summation of effects of several molecules. Furthermore, the PPSB extract did not present acute toxicity nor did it present mutagenic effects.

Conclusion: It can be concluded that the PPSB extract is potentially useful in controlling the postprandial glycaemic levels in diabetes. Further clinical studies with the extract are needed, however, to confirm its potential use in the management of type 2 diabetes.

Keywords: Antioxidant activity, Digestive enzymes, a-Amylase, Enzyme inhibition, Type 2 diabetes

\footnotetext{
*Correspondence: favseixas@uem.br; rmperalta@uem.br

${ }^{5}$ Graduate Program in Molecular and Cellular Biology, Universidade Estadual

de Maringá, bloco 189, Av. Colombo, 5790 - Jd. Universitário, Maringá, PR

87020-900, Brazil

'Department of Biochemistry, Graduate Program in Food Science,

Universidade Estadual de Maringá - UEM, bloco 189, Av. Colombo, 5790 - Jd.

Universitário, Maringá, PR 87020-900, Brazil

Full list of author information is available at the end of the article
}

\section{Springer Open}

( ) The Author(s). 2020 Open Access This article is licensed under a Creative Commons Attribution 4.0 International License, which permits use, sharing, adaptation, distribution and reproduction in any medium or format, as long as you give appropriate credit to the original author(s) and the source, provide a link to the Creative Commons licence, and indicate if changes were made. The images or other third party material in this article are included in the article's Creative Commons licence, unless indicated otherwise in a credit line to the material. If material is not included in the article's Creative Commons licence and your intended use is not permitted by statutory regulation or exceeds the permitted use, you will need to obtain permission directly from the copyright holder. To view a copy of this licence, visit http://creativecommons.org/licenses/by/4.0/. 


\section{Introduction}

Diabetes mellitus is one of the most common public health problems in the world, and type 2 diabetes accounts for $90-95 \%$ of all cases of diabetes [1]. Hyperglycaemia resulting from diabetes can cause serious chronic metabolic diseases, including nephropathy, urinary problems, skin infections and cardiovascular diseases [2]. Thus, it is necessary to explore new alternative therapeutic methods including natural antidiabetic agents.

A practical approach to control blood glucose levels is through natural products isolated from plants that act by retarding the absorption of carbohydrates during digestion and consequently decrease glucose release into blood. This could be achieved through the inhibition of carbohydrate hydrolysing enzymes, such as salivary and pancreatic amylases, and intestinal disaccharidases, $\alpha$ glucosidase, $\beta$-galactosidase, and $\beta$-fructofuronosidase (invertase). Currently, there is renewed interest in plantbased medicines and functional foods modulating physiological effects caused by the inhibition of these enzymes. Polyphenols, including condensed and hydrolysable tannins, gallic acid and green tea catechins have been described as possessing elevated antioxidant activities and potent capabilities to inhibit carbohydrate hydrolysing enzymes, especially $\alpha$-amylases [3-7].

Carbohydrate hydrolysing enzyme inhibitors derived from edible food-grade plants, most of them traditionally used as herbal teas, are the ideal candidates as alternative hypoglycaemic agents [7]. However, non-food grade plants could be, at least in principle, interesting sources of carbohydrate hydrolysing enzyme inhibitors after confirmation of their safety for oral administration. Examples of the last group include the aqueous leaves extract of Zanthoxylum armatum DC [8] and Asparagus racemosus Willd [9]. The stem barks of Artocarpus heterophyllus [10], Acacia mearnsii [3], Myristica fatua Houtt. var. magnifica (Bedd.) Sinclair [11], and Ficus exasperata Vahl [12] are also described as efficient carbohydrate hydrolysing enzyme inhibitors. Poincianella pluviosa (DC.) L.P. Queiroz could be another example. This plant is member of Fabaceae, one of the most important neotropical families. This tree is known as the "sibipiruna" or "false Brazil wood", and is also reported under three synonyms: Caesalpinia peltophoroides (Benth.), Caesalpinia pluviosa var. peltophoroides (Benth.) G.P. Lewis and Caesalpinia pluviosa DC $[13,14]$. The stem bark of $P$. pluviosa has therapeutic properties such as antimalarial activity, wound healing and antidiarrheal activities [14-17]. The decoction of the bark of P. pluviosa is also used in the Bolivian folk medicine for treatment of dysentery [16]. Recently, antimalarial compounds have been shown to occur in the leaves of P. pluviosa [18].

Different molecules, potentially recognized as having functional properties, have already been identified in the aqueous alcohol extract of the stem bark of $P$. pluviosa including pyrogallol, gallic acid, gallic acid methyl ester, ellagic acid, corilagin, 1,4,6-tri- $O$-galloyl-glucose, 1,2,3,6tetra-O-galloyl-glucose, 1,2,3,4,6-penta- $O$-galloyl-glucose tellimagrandin I, tellimagrandin II, mallotinic acid, mallotusinic acid, and geraniin [14]. In spite of these identifications, to our knowledge, there have been no attempts to evaluate the antioxidant potential of this material as well as its possible inhibitory activity on carbohydrate hydrolysing enzymes. Taking these gaps into account, the objectives of the present study were to quantify the antioxidant activity of the aqueous alcohol extract of the stem bark of $P$. pluviosa and to investigate its possible effects on a set of carbohydrate hydrolysing enzymes, namely $\alpha$-amylase, $\alpha$-glucosidase, $\beta$-galactosidase, $\alpha$ glucosidase, and $\beta$-fructofuronosidase. Efforts were also undertaken in order to assert the safety of the extract, especially after oral administration, in order to obtain a more or less complete picture of its potentialities as a future alternative therapeutic agent.

\section{Material and methods \\ Materials}

Porcine pancreatic $\alpha$-amylase (Type VI-B), human salivary $\alpha$ amylase and acarbose (empirical formula $\mathrm{C}_{25} \mathrm{H}_{43} \mathrm{NO}_{18}$, molecular weight 645), and diphenyl-1-picrylhydrazyl (DPPH) were purchased from Sigma-Aldrich Co. Barks of P. pluviosa were collected at the campus of the University of Maringá

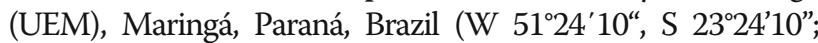
$\mathrm{h}=490 \mathrm{~m}$ ) A voucher specimen was deposited in the herbarium of the Universidade Estadual de Maringá under number HUEM-33834. Access to the botanical material was registered by the Brazilian Biodiversity System - SisGen - Sistema Nacional de Gestão do Patrimônio Genético e do Conhecimento Tradicional Associado under id A6DD2D2.

\section{Preparation of the aqueous alcohol extract from $P$. pluviosa stem bark (PPSB extract)}

The aqueous alcohol extract of $P$. pluviosa stem bark (PPSB extract) was prepared as described previously [14]. Briefly, the dried stem barks were milled and subjected to turbo extraction (Ultra-turrax UTC115KT, Ika Works, USA) using 50\% ethanol in water (v/v) as solvent. The turbo extraction is done by a device called turbo extractor in which a rotor with radial-mounted paddles distributes the product against a perforated screen and thus obtains the separation of soluble parts from solid components. Ethanol was further eliminated with a rotary evaporator under reduced pressure and, finally, the material was lyophilized.

\section{Analysis of total phenolic and flavonoid contents}

Total phenolic contents in extracts were determined by the Folin-Ciocalteu reagent and expressed as gallic acid 
equivalents [19]. The determination of flavonoids was done by means of a colorimetric assay and expressed as catechin equivalents [20].

\section{Evaluation of the antioxidant activity of the $P$. pluviosa aqueous alcohol extract}

Two different methods were used to evaluate the antioxidant activity: reduction of the 2,2-diphenyl-1-picrylhydrazyl radical (DPPH), and reduction power of the ferric ion (FRAP). For the DPPH assay, successive dilutions of the stock solution were made and used for assaying the antioxidant activity of the samples. The DPPH assay was conducted as described previously [21]. The percentage of DPPH discoloration (D\%) was calculated using the following equation:

$$
D(\%)=\frac{A_{\text {control }}-A_{\text {sample }}}{A_{\text {control }}} \times 100
$$

The results were expressed as $\mathrm{IC}_{50}$ values (sample concentration providing $50 \%$ of antioxidant activity). FRAP was evaluated as previously described [21]. Standard curves were constructed with trolox $\left(\mathrm{r}^{2}=0.99\right)$ and the results were expressed as mmol trolox equivalents (TE)/ mg lyophilised material.

\section{Evaluation of the inhibitory effects of the P. pluviosa aqueous alcohol extract on porcine pancreatic amylase and the human salivary amylase}

The inhibition experiments with the porcine pancreatic $\alpha$ amylase and the human salivary $\alpha$-amylase were carried out as described previously using potato starch at $1.0 \mathrm{~g} /$ $100 \mathrm{~mL}$ as substrate [3]. The specific activity of both enzymes was 500 units $/ \mathrm{mg}$ protein. The amount of enzyme added to each reaction system was 1 unit. The reaction was allowed to proceed for $10 \mathrm{~min}$. The reducing sugars resulting from the starch hydrolysis were assayed by the 3 , 5-dinitrosalicylic acid method, using maltose as standard [22]. The $\mathrm{pH}$ of the reaction medium was tested for all situations. No changes were detected during the incubation time. The inhibition of $\alpha$-amylase activity was calculated by the following equation:

$$
\operatorname{Inhibition}(\%)=\left(1-\frac{A B S_{\text {sample }}}{A B S_{\text {control }}}\right) \times 100
$$

where $\mathrm{ABS}_{\text {sample }}$ is the absorbance at $540 \mathrm{~nm}$ of the incubation containing enzyme plus sample plus substrate; $\mathrm{ABS}_{\text {control }}$ is the absorbance at $540 \mathrm{~nm}$ of the incubation containing enzyme plus substrate.

\section{Preparation of intestinal enzymes and evaluation of inhibition of disaccharidases}

A segment of the small intestine of the rat was removed, washed in $50 \mathrm{mM}$ sodium phosphate buffer ( $\mathrm{pH} 6.5)$, dried on filter paper, weighed, trimmed, and homogenized $(300 \mathrm{rpm})$ with the same buffer $(400 \mathrm{mg}$ of duodenum per milliliter) for $1 \mathrm{~min}$ at $4{ }^{\circ} \mathrm{C}$. The resulting extract was centrifuged at $5000 \mathrm{rpm}$ for $10 \mathrm{~min}$. The supernatant was used for the measurement of $\alpha$ glucosidase (EC. 3.2.1.20), fructofuranosidase (EC 3.2.1.48), and $\beta$-galactosidase (EC 3.2.1.23) activities. The three activities were determined using a glucose diagnosis kit based on the glucose oxidase reagent. For determination of disaccharidase activities, the incubation system containing $25 \mathrm{mM}$ sucrose, lactose, or maltose dissolved in $50 \mathrm{mM}$ sodium phosphate buffer ( $\mathrm{pH} 6.0)$ and the appropriate enzyme extract volume were incubated for $60 \mathrm{~min}$ at $37^{\circ} \mathrm{C}$. At the end of this time, $1 \mathrm{~mL}$ of the color reagent solution containing glucose oxidase and peroxidase was added and the mixture was incubated at $37^{\circ} \mathrm{C}$ for $20 \mathrm{~min}$. The absorbance was read at $505 \mathrm{~nm}$, and the activity calculation was based on a glucose standard. One enzyme unit was defined as the amount of enzyme that catalyzed the release of $1 \mu \mathrm{mol}$ of glucose per minute under the assay conditions. Percentage of inhibition was calculated using Eq. (2). For this calculation $\mathrm{ABS}_{\text {sample }}$ is the absorbance at $505 \mathrm{~nm}$ of the incubation containing enzyme plus sample plus substrate; $\mathrm{ABS}_{\text {control }}$ is the absorbance at $505 \mathrm{~nm}$ of the incubation containing enzyme plus substrate.

\section{In vivo inhibition of gastrointestinal enzymes}

Male healthy Wistar rats weighing 200-250 g were used in the intestinal enzymes experiments and glycemic levels. Previous to the investigations, the animals were kept for 10 days under standard environmental conditions with access to standard pelleted food and water ad libitum. Food was withdrawn $18 \mathrm{~h}$ before the experiments. Rats were assigned into 6 groups ( $n=4$ rats per group). To group I (positive control) commercial corn starch ( $1 \mathrm{~g}$ per $\mathrm{kg}$ body weight) was administered intragastrically. Group II (negative control) received only tap water. To group III (control) commercial corn starch plus acarbose was given intragastrically $(50 \mathrm{mg} / \mathrm{kg})$. Groups IV, V and VI received intragastrically commercial corn starch plus PPSB extract at doses of 100, 250 and $500 \mathrm{mg} / \mathrm{kg}$. The concentrations of the inhibitors given to the rats were based on previous studies [3]. Fasting blood glucose levels were determined before the administration of starch and amylase inhibitors (0 time). Subsequent evaluations of blood glucose levels took place every $15 \mathrm{~min}$ for $60 \mathrm{~min}$. Blood glucose from cut tail tips was determined using Accu-Chek ${ }^{\circ}$ Active Glucose Meter.

\section{Docking simulations}

The structure of porcine pancreatic alpha-amylase (PDBid 312 l) at $2.11 \AA$ resolution [23] was used in the docking simulations. All ligands were removed except $\mathrm{Ca}^{2+}$ and $\mathrm{Cl}^{-}$cofactors. Next, the structure of the human 
pancreatic alpha-amylase (PDBid: 1xd0) bound to acarbose pentasaccharide (ACA) [23] was superimposed on the porcine pancreatic alpha-amylase, so the ACA ligand and the water molecules 511, 513 and 766 were copied to the porcine pancreatic alpha-amylase (geometric docking). The modeled complex of porcine alphaamylase bonded to ligand ACA and cofactors was minimized by conjugate gradient (CG) in steps, using the NAMD2 program [24] to prevent stereochemical clashes. First, the coordinates were placed in a periodic box filled with Tip3 water and sufficient amount of sodium counterions to neutralize the system charges, and then, it was minimized by 20,000 steps of CG with the atoms of ligands and cofactors fixed in space. In the second step, the atoms of the protein and ligand were fixed in space and water molecules and ions submitted to 60 ps of molecular dynamics under NPT conditions. In the third and last step, the whole system was minimized again by new 20,000 steps of CG. The CHARMM C35b2-C36a2 force field [25] was used for simulation of protein, water and ions. The force field for ACA was generated by the Swissparam server in the same format. The partial charges of its atoms were calculated by the B3LYP/6-311G method using the ORCA program (https://orcaforum.cec.mpg.de/). The final minimized structure was used in the docking simulations by means of three programs. The first program was AutoDock4.2.3 [26] implemented in the Pyrx-0.9 graphical interface [27]. The search box was centralized at the ligand with grid dimensions of 50 at the $\mathrm{x}, \mathrm{y}$ and $\mathrm{z}$ axis. The number of runs was increased to 40 due to the large number of rotatable bonds of the ligands. The second program was Molegro-6.0 virtual docker using $12 \AA$ as search radius centralized at the ligand. The Moldock Simplex Evolution and Moldock Score [grid] algorithms for search and ranking were used respectively. The third program was the Gold using chemplp method as fitness and search option with 40 runs. The library containing 14 compounds identified in the Poincianella pluviosa extract [14] was obtained from the PubChem, Zinc15 and ChEMBL databases in the "sdf format. The compounds better ranked than the ACA inhibitor, by each program, in the average of 10 simulations and in common by all programs were classified as those with the highest binding potential.

\section{Acute toxicity test}

Swiss mice were assigned into 6 groups ( 5 males and 5 females per group) and maintained under controlled temperature $\left(22^{\circ} \mathrm{C}\right)$, with a constant $12 \mathrm{~h}$ light-dark cycle and access to standard pelleted food (Nuvital $)$ and water ad libitum. The acute toxicity studies were performed according to the guidelines of the Brazilian National Health Surveillance Agency (ANVISA). The negative control group (control, group I) received only the vehicle (saline) and the other groups, II, III, IV and V, received intragastrically single doses of PPSB extract. These doses were 2.0, $3.0,4.0$ and $5.0 \mathrm{~g} / \mathrm{kg}$, respectively $(0.5 \mathrm{~mL}$ per animal). The general behaviour of the mices was monitored continuously during the first $24 \mathrm{~h}$ after dosing and daily thereafter for 14 days. The animals were observed daily for clinical signs as activity and coordination of the motor system and muscle toning, activities relating to the autonomic nervous system (salivation, cyanosis, piloerection), activities relating to the central nervous system (tremors, convulsions) and activity of the respiratory system. Further observations were related to the possibility of diarrhea, lethargy or sleep, abnormal behavior and mortality (median lethal dose, $\left.\mathrm{LD}_{50}\right)$. At the end of the observation period, the animals were anesthetized with thiopental $(120 \mathrm{mg} / \mathrm{kg})$ and after euthanasia, organs as heart, lung, kidneys, liver and spleen were collected, weighed and examined macroscopically.

\section{Mutagenicity test}

Swiss mice were assigned into 6 groups ( 5 males and 5 females per group) and treated intragastrically with a single dose. The negative group received saline. The positive group received only cyclophosphamide $(50 \mathrm{mg} /$ $\mathrm{kg}$ ) and the test group received PPSB extract at the dose of $3.0 \mathrm{~g} / \mathrm{kg}$. Twenty-four hours after, all animals were euthanized with thiopental $(120 \mathrm{mg} / \mathrm{kg})$ and the femoral pairs were collected. In sequence, the proximal epiphyses were cleaned with saline and sectioned. Subsequently, the bone marrow was removed, washed with fetal calf serum, and centrifuged ( $3000 \mathrm{rpm}, 5 \mathrm{~min}$ ). Smears of airdried sediment were stained with May-GrunwaldGiemsa and analysed by light microscopy $(1000 \times)$ for detecting the presence of micronucleated polychromatic erythrocytes. The experiments were done in duplicate and the micronucleated polychromatic erythrocytes were determined by counting 1000 red cells. A mutagenic effect was assumed when a significant increase in micronucleated polychromatic erythrocytes was observed when compared to the negative control [28].

\section{Data analyses}

Statistical analysis was performed using the GraphPad Prism software (version 5.0). The data were expressed as the mean \pm standard deviation, and were analysed using oneway analysis of variance (one-way ANOVA). Significant differences were determined by the Tukey test for homogeneous data and the Kruskal-Wallis test for heterogeneous data. Differences were considered significant at $p \leq 0.05$.

\section{Ethical aspects}

All experiments involving animals were done in conformity with the worldwide accepted ethical guidelines for animal experimentation and approved by the Ethics 
Table 1 Total phenolics, flavonoids and antioxidant activity of the P. pluviosa aqueous alcohol extract

\begin{tabular}{ll}
\hline PPSB extract property & quantity \\
\hline Total phenolics $(\mathrm{mg} \mathrm{GAE} / \mathrm{g})$ & $494.51 \pm 27.69$ \\
Total flavonoids $(\mathrm{mg} \mathrm{CAE} / \mathrm{g})$ & $25.73 \pm 0.25$ \\
$\mathrm{DPPH}\left(\mathrm{I} \mathrm{C}_{50}\right)(\mu \mathrm{g} / \mathrm{mL})$ & $6.40 \pm 0.35$ \\
FRAP $(\mu \mathrm{M}$ TE/ mg) & $4.75 \pm 0.16$ \\
\hline
\end{tabular}

Data represented as mean \pm SD. $N=3$. GAE Gallic acid equivalent. CAE Catechin equivalent. TE Trolox equivalent

Committee for Animal Experimentation of the University of Maringá (Process 090/2011; Protocol 056/2009). The evaluation of acute toxicity and the mutagenicity studies were performed according to the standards of the "Guide for conducting non-clinical toxicology studies and safety pharmacology necessary for the development of drugs" [29].

\section{Results and discussion}

Analysis of total phenolic and flavonoid contents and antioxidant activity of the PPSB extract

The phenolics and flavonoids contents as well as the antioxidant activity of the P. pluviosa stem bark extract are shown in Table 1. The material was rich in both phenolics and flavonoids. The antioxidant activity of the PPSB extract was evaluated by two methods, DPPH radical scavenging and FRAP (ferric ion reducing capacity) (Table 1). Concentrations of the PPSB extract for halfmaximal antioxidant activities were similar for both assays and within the $1-10 \mu \mathrm{g} / \mathrm{mL}$ range.

The stem bark of the Poincianella pluviosa extract contains high amounts of phenolics and flavonoids. Such richness in phenolics and flavonoids is in agreement with data reported for similar extracts including Caesalpinia spinosa extract (551 mg of GAE/g) [30], Caesalpinia decapetala methanolic extract $(13.28 \mathrm{mg}$ of GAE/g of phenolics and $3.93 \mathrm{mg}$ quercetin/g of flavonoids) [31] and ethanolic extracts of seeds of Caesalpinia bonducella (62.50 mg of GAE/g of phenolics) [32].

The high antioxidant activity found in the PPSB extract can be explained by its richness in chemical compounds which include gallic acid, gallic acid methyl ester, pyrogallol, ellagic acid, corilagin, 1,4,6-tri-O-galloyl-glucose, tellimagrandin I, 1,2,3,6-tetra- $O$-galloyl-glucose, mallotinic acid, tellimagrandin II, 1,2,3,4,6-penta-
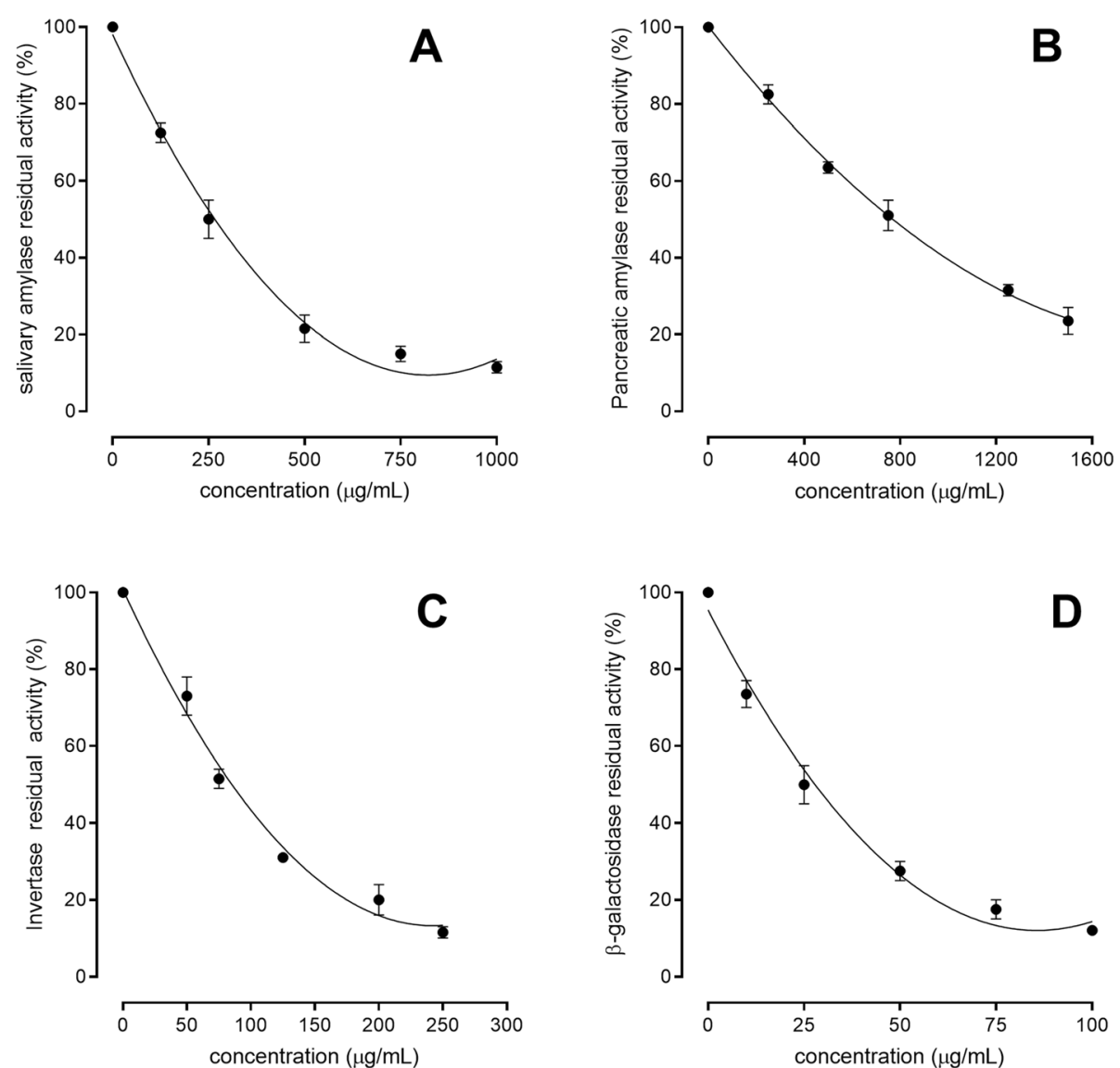

Fig. 1 The inhibitory effects of the aqueous alcohol extract of $P$. pluviosa on carbohydrate digestive enzymes relevant to type 2 diabetes: a salivary a-amylase; $\mathbf{b}$ pancreatic a-amylase; $\mathbf{c}$ intestinal invertase; $\mathbf{d}$ intestinal $\beta$-galactosidase. Results are expressed as mean \pm mean standard errors of three experiments 
$O$-galloyl-glucose, geraniin and mallotusinic acid as previously described [14]. It should be stressed that the antioxidant activity of the Poincianella pluviosa extract used in the present work exceeds that of Caesalpinia bonducella bark and seed extracts by a factor above ten [32], as the latter presented $\mathrm{IC}_{50}$ values of $83.69 \pm$ $0.14 \mu \mathrm{g} / \mathrm{mL}$ and $74.73 \mu \mathrm{g} / \mathrm{mL}$, respectively, for the DPPH free radical scavenging activity (Table 1 ).

\section{Effects of the PPSB extract on the activities of carbohydrate digestive enzymes}

The effects of the PPSB extract on the activities of carbohydrate digestive enzymes, salivary amylase, pancreatic amylase and intestinal disaccharidases (invertase and $\beta$-galactosidase) are illustrated by Fig. 1. Both salivary and pancreatic amylases were inhibited by the extract (panels A and B). However, the salivary amylase was more intensely inhibited, if one considers the $\mathrm{IC}_{50}$ values (concentrations of extract causing 50\% inhibition) which were $250 \pm 15 \mu \mathrm{g} / \mathrm{mL}$ and $750 \pm 15 \mu \mathrm{g} / \mathrm{mL}$ for the salivary and pancreatic amylase, respectively. The inhibitory effects of the PPSB extract on the activities of the intestinal disaccharidase enzymes are also illustrated by Fig. 1. The extract effectively inhibited the invertase and $\beta$-galactosidase (Fig. 1c,d). It was a more efficient inhibitor of $\beta$-galactosidase than of invertase, with $\mathrm{IC}_{50}$ values of $25 \pm 5 \mu \mathrm{g} / \mathrm{mL}$ and $75 \pm 8 \mu \mathrm{g} / \mathrm{mL}$, respectively. No inhibition was found in the case of the $\alpha$-glucosidase (not shown) even at the high concentration of $250 \mu \mathrm{g} / \mathrm{mL}$ $(p \geq 0.05)$.

To test the effectiveness of the PPSB extract as inhibitor of starch hydrolysis in vivo, experiments were done in which the blood glucose levels were measured in rats after the administration of commercial corn starch. Intragastric administration of starch to rats should increase blood glucose. One can expect that the PPSB extract, on the other hand, diminishes or abolishes this increase if its components also inhibit starch hydrolysis in vivo. Three different doses of PPSB were administered intragastrically as described in the Materials and methods section. Acarbose $(50 \mathrm{mg} / \mathrm{kg})$, a well known amylase inhibitor [33], was used as a positive control. The administration of starch alone resulted in a rapid increase in the blood glucose levels (Fig. 2). For the control rats the glycemic levels remained essentially constant.

Both acarbose and the PPSB extract prevented to a considerable extent the elevation of blood glucose. This test was done considering that hydrolysis of intragastrically administered starch is a prerequisite for the entrance of the derived glucosyl units into blood. This phenomenon can be best appreciated by comparing the areas under the glycemic curves in Fig. 3. The areas were computed numerically and subtracted from the area

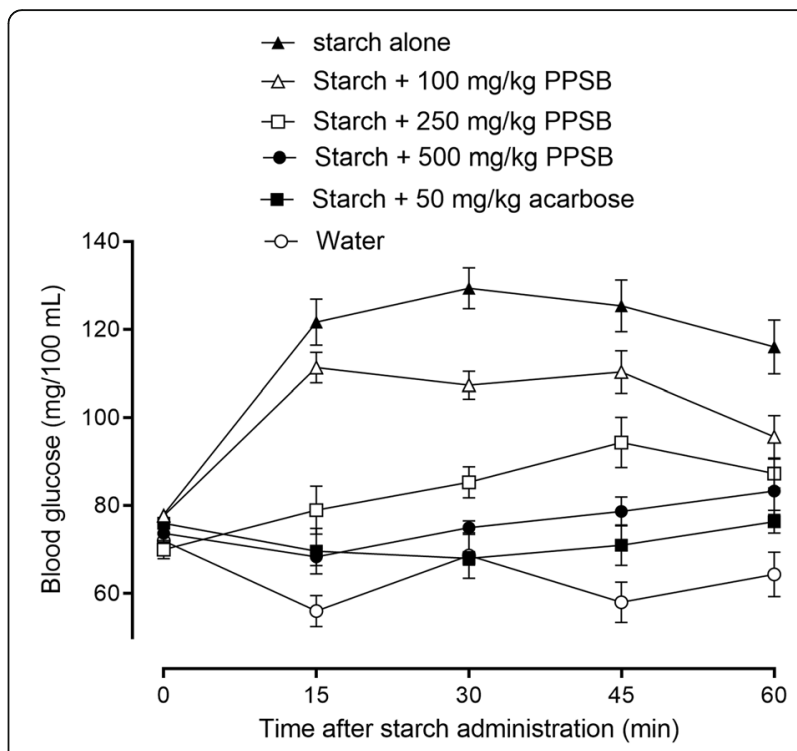

Fig. 2 Influence of the P. pluviosa aqueous alcohol extract (PPSB) administration on the glycemic levels of fasting rats during $60 \mathrm{~min}$ following starch administration. Each datum point represents the mean \pm mean standard errors of four experiments. Experimental details are given in the Materials and methods section

under the curve obtained when water was administered alone. This area can be regarded as a measure of the extra glucose in the circulating blood during the first 60 min following starch and PPSB extract administration.

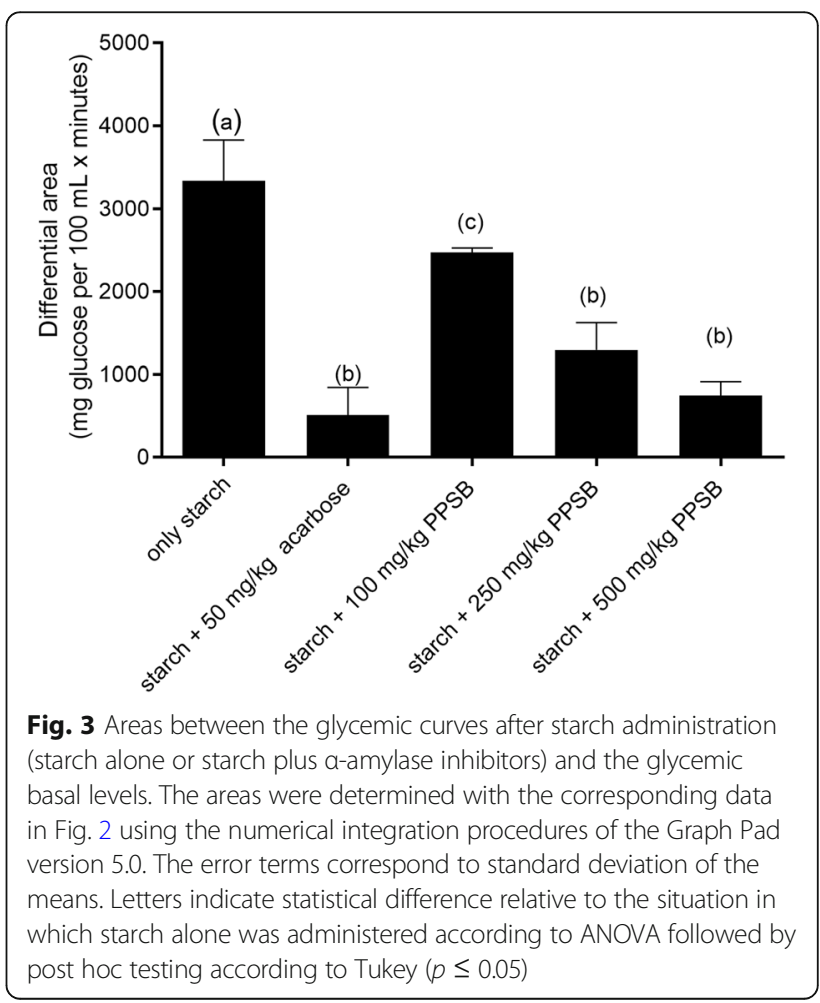




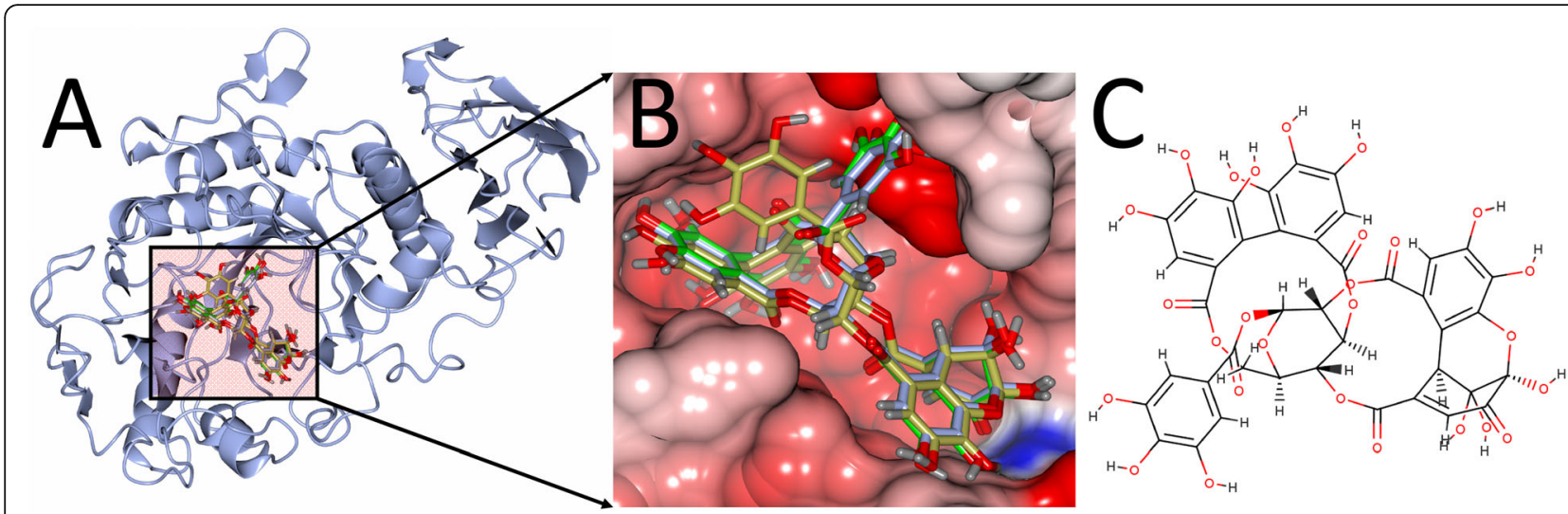

Fig. 4. a Docking of the ligand geraniin on the catalytic site of pig pancreatic alpha-amylase showing that all the programs evaluated found the same pose for this ligand with few differences. $\mathbf{b}$ The pose found by Autodock is in green, the pose found by Molegro is in blue and pose found by Gold is in gold. c Chemical structure of geraniin (PubChem CID: 3001497)

Figure 3 reveals that the action of the PPSB extract showed a well-defined dose-dependent action. The lowest dose $(100 \mathrm{mg} / \mathrm{kg})$ already diminished the glycemic response by $25 \%$; with the highest dose $(500 \mathrm{mg} / \mathrm{kg})$ the diminution reached $75 \%$.

It is evident that the inhibition of amylases by the PPSB extract was dose-dependent, but complete inhibition was not achieved with concentrations up to $1000 \mu \mathrm{g} / \mathrm{mL}$ (salivary amylase) or $1500 \mu \mathrm{g} / \mathrm{mL}$ (pancreatic amylase). However, total inhibition of amylases may not be of interest because previous studies indicate that excessive inhibition of the pancreatic $\alpha$-amylase can result in side effects through abnormal bacterial fermentation of undigested carbohydrates in the colon [34]. Complete inhibition of especially the pancreatic amylase would possibly necessitate very high concentrations in the intestine which would require, in turn, the ingestion of very high and impracticable doses. Hence, it is unlikely that a situation of excessive inhibition of the pancreatic amylase could be produced by accident. Previous studies have shown that antioxidant phenolics such as gallic acid, flavonoids, and condensed and hydrolysable tannins are also inhibitors of carbohydrate digestive enzymes [3, 6, 33-42]. So, the inhibitory effect of PPSB extract on the carbohydrate digestive enzymes may also be attributed to its richness in phenolics, including gallic acid, flavonoids and tannins [14].

\section{Identification of the compound from the extract with higher enzyme binding potential}

Docking simulations were done in order to investigate which of the components of the extract has greater potential of binding to alpha-amylase. To make the result as reliable as possible, three different programs using

Table 2 Weight of organs of male and female rats treated for 14 days with different amounts of PPSB extract

\begin{tabular}{|c|c|c|c|c|c|c|}
\hline & \multicolumn{6}{|c|}{ Weight $(g)$ (mean \pm SD) } \\
\hline & Organs & Control & $\begin{array}{l}\| \\
2.0 \mathrm{~g} / \mathrm{kg}\end{array}$ & $\begin{array}{l}\text { III } \\
3.0 \mathrm{~g} / \mathrm{kg}\end{array}$ & $\begin{array}{l}\text { IV } \\
4.0 \mathrm{~g} / \mathrm{kg}\end{array}$ & $\begin{array}{l}\mathrm{V} \\
5.0 \mathrm{~g} / \mathrm{kg}\end{array}$ \\
\hline \multirow[t]{5}{*}{ Male } & Spleen & $0.63 \pm 0.07$ & $0.41 \pm 0.08$ & $0.58 \pm 0.09$ & $0.75 \pm 0.11$ & $0.61 \pm 0.10$ \\
\hline & Heart & $0.57 \pm 0.03$ & $0.43 \pm 0.03$ & $0.47 \pm 0.07$ & $0.55 \pm 0.02$ & $0.53 \pm 0.05$ \\
\hline & Liver & $5.72 \pm 0.66$ & $4.25 \pm 0.51$ & $4.67 \pm 0.77$ & $6.05 \pm 0.72$ & $5.75 \pm 0.83$ \\
\hline & Lungs & $0.63 \pm 0.09$ & $0.68 \pm 0.04$ & $0.71 \pm 0.06$ & $0.74 \pm 0.09$ & $0.69 \pm 0.10$ \\
\hline & Kidney & $1.57 \pm 0.11$ & $1.08 \pm 0.09$ & $1.20 \pm 0.12$ & $1.79 \pm 0.17$ & $1.51 \pm 0.07$ \\
\hline \multirow[t]{5}{*}{ Female } & Spleen & $0.55 \pm 0.07$ & $0.57 \pm 0.04$ & $0.60 \pm 0.10$ & $0.56 \pm 0.06$ & $0.65 \pm 0.09$ \\
\hline & Heart & $0.49 \pm 0.06$ & $0.78 \pm 0.11$ & $0.69 \pm 0.11$ & $0.46 \pm 0.05$ & $0.46 \pm 0.05$ \\
\hline & Liver & $5.15 \pm 0.36$ & $5.81 \pm 0.54$ & $5.92 \pm 0.98$ & $5.76 \pm 0.24$ & $5.01 \pm 0.64$ \\
\hline & Lungs & $0.68 \pm 0.08$ & $0.78 \pm 0.07$ & $0.65 \pm 0.33$ & $0.67 \pm 0.10$ & $0.74 \pm 0.09$ \\
\hline & Kidney & $1.46 \pm 0.14$ & $1.93 \pm 0.15$ & $1.91 \pm 0.32$ & $1.31 \pm 0.07$ & $1.41 \pm 0.18$ \\
\hline
\end{tabular}



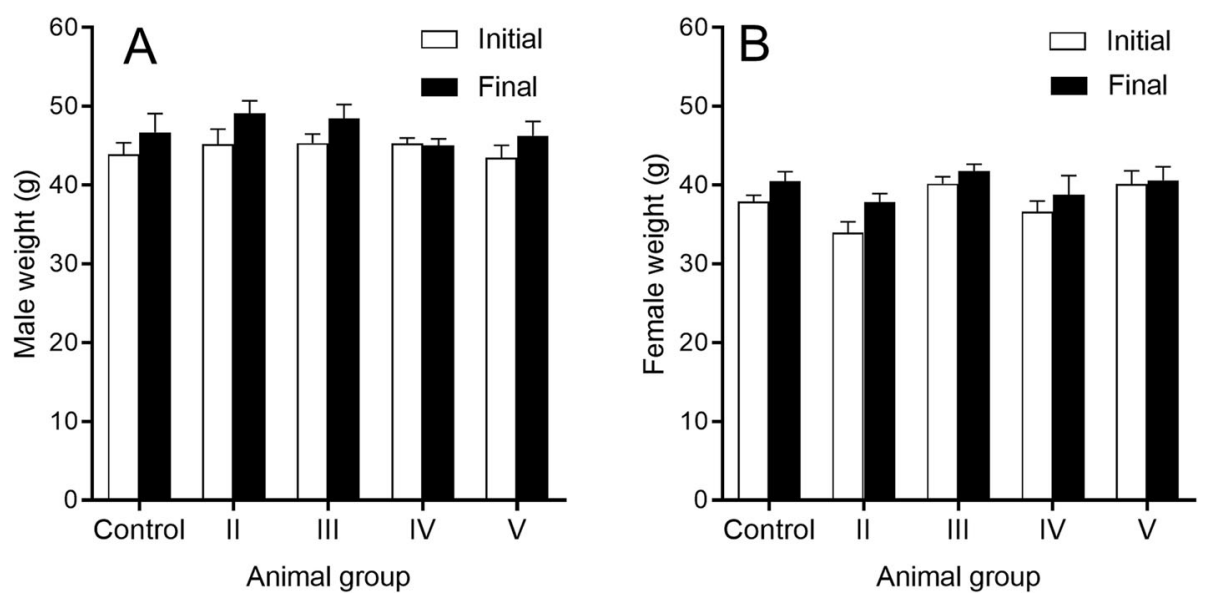

Fig. 5 Initial and final body weight of male (a) and female (b) rats treated for 14 days with different amounts of PPSB extract

different search and rank algorithms were employed. Thus, if a single ligand is selected with the best score and with reproducibility by the three different programs, the chances of this ligand being a false-positive drastically decrease. To make the selection criterion even more stringent, the molecule chosen in common should exhibit the same pose on protein binding, in all replicates by all programs. The mean scores found are shown in Table S1 (supplementary data). Of the three programs employed, Autodock was the least selective. It is clear that docking score should not be interpreted as binding affinity, since the latter can only be estimated by calculations and confirmed by binding kinetic assays with the enzyme. The docking simulation only selects the molecule with the physico-chemical requirements needed to fit in a particular site of the protein. However, if different programs find the same pose for a given molecule, in all the simulations, the greater are the chances of it being a true ligand. As a result, the geraniin molecule (CID3001497) was the one that had a higher score than the reference ligand ACA and, in all the simulations it presented the same binding pose (Fig. 4). In fact, geraniin has a known anti-hyperglycemic activity [43, 44], what gives even more reliability to the results.

The results presented herein suggest that geraniin would be the component with the greatest binding potential among all others. However, there are other molecules present in the Poincianella pluviosa extract which also have known alpha-amylase inhibitory activity. Corilagin [45], for example, acts as a mixed inhibitor of the enzyme, and 1,2,3,4,6-penta-O-galloyl-glucose (pentagalloyl-glucose, PGG) has recently been described as a competitive inhibitor [38]. Other components of the extract may eventually act as inhibitors of alpha-amylases. Consequently, the inhibition of both salivary and pancreatic amylases by the PPSB extract results more likely from a summation of effects of several molecules.
Safety evaluation of the PPSB extract upon oral administration

No mortality or clinical symptoms attributable to the PPSB extract were observed upon oral administration during the 14 days period. The males treated with the $2.0 \mathrm{~g} / \mathrm{kg}$ dose showed a tendency toward diminution of the weight of several organs, the opposite occurring with the females (Table 2). These tendencies, however, lacked statistical significance at the $5 \%$ level and were not confirmed when the doses were increased. Additionally, the body weight gains of control and treated groups were similar and showed no statistically significant differences (Fig. 5). This observation corroborates the suggestion that the PPSB extract does not impair in a deleterius manner physiological functions or nutrient absorption.

The results of the mutagenicity assays are presented in Table 3. No deaths were observed during the experiment. The administration of $3.0 \mathrm{~g} / \mathrm{kg}$ of PPSB did not result in significant modification in the number of micronucleated polychromatic erythrocytes compared to the negative control group. However, as expected, the positive control group presented a pronounced increase.

Table 3 Number of micronucleated polychromatic erythrocytes (MPE) per 1000 red cells

\begin{tabular}{lll}
\hline Group & gender & MPE per 1000 red cells \\
\hline Positive group & Male & $31.6 \pm 2.1^{*}$ \\
& Female & $25.3 \pm 4.0^{*}$ \\
Negative group & Male & $5.5 \pm 1.0$ \\
& Female & $3.8 \pm 1.0$ \\
PPSB extract & Male & $5.4 \pm 0.9$ \\
$(3.0 \mathrm{~g} / \mathrm{kg})$ group & Female & $5.3 \pm 0.6$ \\
\hline
\end{tabular}

The data are expressed as mean \pm S.D. $(n=5)$. Asterisks $\left.{ }^{*}\right)$ indicate significant differences ( $p \leq 0.05$ with respect to the PPSB extract group. The positive group received cyclophosphamide, $50 \mathrm{mg} / \mathrm{kg}$. The negative group received saline 
Our results showed that the PPSB extract lacks acute toxicity and did not exert mutagenic effects. The emergence of significant changes in the organ and animal weights used to assess acute toxicity serve as a sensitive indicator of the general health status and to evaluate the toxic effect of drugs [15]. Furthermore, the evaluation of mutagenicity by the micronucleus test is considered an effective pre-clinical toxicity test to detect changes caused by mutagens [28].

\section{Conclusion}

In conclusion, the stem bark aqueous alcohol extract of Poincianella pluviosa (PPSB extract) inhibits several carbohydrate digestive enzymes relevant to type 2 diabetes: salivary and pancreatic amylases, $\beta$-galactosidase, and invertase. However, the intestinal $\alpha$-glucosidase was not inhibited by the extract. Docking simulations suggest that the dehydroellagitannin, geraniin, presents the greatest binding potential to the pancreatic alphaamylase, being a potent inhibitor of the enzyme. The PPSB extract was also able to inhibit the intestinal starch absorption in rats. It can be concluded that the PPSB extract is potentially useful in controlling the postprandial glycemic levels in diabetes. The high antioxidant activity and an efficient inhibitory action on carbohydrate digestive enzymes, may be regarded as being relevant to type 2 diabetes. Chronic hyperglycemia associated with type 2 diabetes leads to an imbalance in the redox homeostasis at the cellular level due to the uncontrolled production of harmful reactive oxygen species. Thus, the phenoliclinked antioxidant activity of the PPSB extract found in this study offers the perspective that it could represent a potential aid in the reduction of oxidative stress mediated by hyperglycemia. Further clinical studies with the extract are needed, however, to confirm its potential use in the management of type 2 diabetes.

\section{Supplementary information}

Supplementary information accompanies this paper at https://doi.org/10. 1186/s40816-020-00177-w.

Additional file 1: Table S1. Software scores found on docking ligands to porcine pancreatic alpha amylase.

\section{Acknowledgments}

Not applicable.

\section{Authors' contributions}

CGKS, ABSN, ACG, GAG conducted biochemical, in vitro and in vivo experiments. FGB, BPMZ, JCPM collect plant material, prepare and analyzed the extract. PSAB, FAVS conducted the in silico evaluations. AB, RMP, JCPM designed the experiment, search for funding and revised the manuscript for intellectual content. All authors read and approved the final draft of the manuscript.

Authors' information

Not applicable.

\section{Funding}

This work was financially supported by grants from the Conselho Nacional de Desenvolvimento Científico e Tecnológico (CNPq), Fundação Araucária [grant numbers 40/16, 53/19]. C. G. Kato-Schwartz and A.C. Guidi were doctoral fellowship recipients of the CAPES, Brazil (Coordenação de Aperfeiçoamento de Pessoal de Nível Superior). J.C.P. de Mello, A. Bracht, and R.M.

Peralta are research grant recipients of CNPq.

Availability of data and materials

The data sets used and/or analyzed during the current study are available from the corresponding author on reasonable request.

Ethics approval and consent to participate

All experiments involving animals were done in conformity with the worldwide accepted ethical guidelines for animal experimentation and approved by the Ethics Committee for Animal Experimentation of the University of Maringá (Process 090/2011; Protocol 056/2009).

\section{Consent for publication}

All the authors participated in developing the manuscript and grant their consent for onward publication.

\section{Competing interests}

The authors declare that they have no competing interests.

\section{Author details}

${ }^{1}$ Department of Biochemistry, Graduate Program in Food Science, Universidade Estadual de Maringá - UEM, bloco 189, Av. Colombo, 5790 - Jd. Universitário, Maringá, PR 87020-900, Brazil. ²Graduate Program in Pharmaceutical Science, Universidade Estadual de Maringá, Maringá, Paraná 87020-900, Brazil. ${ }^{3}$ Medical and Pharmaceutical Center, Universidade Estadual do Oeste do Paraná, Cascavel, Paraná 85819-110, Brazil. ${ }^{4}$ Graduate Program of Phisiology Science, Universidade Estadual de Maringá, Maringá, Paraná 87020-900, Brazil. ${ }^{5}$ Graduate Program in Molecular and Cellular Biology, Universidade Estadual de Maringá, bloco 189, Av. Colombo, 5790 - Jd. Universitário, Maringá, PR 87020-900, Brazil.

Received: 16 January 2020 Accepted: 20 May 2020

Published online: 24 May 2020

\section{References}

1. Wang PC, Zhao S, Yang BY, Wang QH, Kuang HX. Anti-diabetic polysaccharides from natural sources: a review. Carbohydr Polym. 2016;148: 86-97. https://doi.org/10.1016/j.carbpol.2016.02.060.

2. Giovannini P, Howes MJ, Edwards SE. Medicinal plants used in the traditional management of diabetes and its sequelae in Central America: a review. J Ethnopharmacol. 2016;184:58-71. https://doi.org/10.1016/j.jep.2016. 02.034 .

3. Kato CG, De Almeida Gonçalves G, Peralta RA, Seixas FAV, De Sá-Nakanishi AB, Bracht L, Comar JF, Bracht A, Peralta RM. Inhibition of a -amylases by condensed and hydrolysable tannins: focus on kinetics and hypoglycemic actions. Enzyme Res. 2017. https://doi.org/10.1155/2017/5724902.

4. da Silva SM, Koehnlein EA, Bracht A, Castoldi R, de Morais GR, Baesso ML, Peralta RA, de Souza CGM, de Sá-Nakanishi AB, Peralta RM. Inhibition of salivary and pancreatic a-amylases by a pinhão coat (Araucaria angustifolia) extract rich in condensed tannin. Food Res Int. 2014:56:1-8. https://doi.org/ 10.1016/j.foodres.2013.12.004

5. Cheng Q, Cai S, Ni D, Wang R, Zhou F, Ji B, Chen Y. In vitro antioxidant and pancreatic alpha-amylase inhibitory activity of isolated fractions from water extract of Qingzhuan tea. J Food Sci Technol. 2015;52:928-35. https://doi. org/10.1007/s13197-013-1059-y.

6. Lou W, Chen Y, Ma H, Liang G, Liu B. Antioxidant and a-amylase inhibitory activities of tannic acid. J Food Sci Technol. 2018;55:3640-6. https://doi.org/ 10.1007/s13197-018-3292-x.

7. Mahmood N. A review of a-amylase inhibitors on weight loss and glycemic control in pathological state such as obesity and diabetes. Comp Clin Path. 2016;25:1253-64. https://doi.org/10.1007/s00580-014-1967-x.

8. Rynjah CV, Devi NN, Khongthaw N, Syiem D, Majaw S. Evaluation of the antidiabetic property of aqueous leaves extract of Zanthoxylum armatum DC. using in vivo and in vitro approaches. J Tradit Complement Med. 2018;8: 134-40. https://doi.org/10.1016/j.jtcme.2017.04.007. 
9. Vadivelan R, Krishnan RG, Kannan R. Antidiabetic potential of Asparagus racemosus Willd leaf extracts through inhibition of a-amylase and aglucosidase. J Tradit Complement Med. 2019;9:1-4. https://doi.org/10.1016/j. jtcme.2017.10.004.

10. Ajiboye BO, Ojo OA, Adeyonu O, Imiere OD, Fadaka AO, Osukoya AO. Ameliorative activity of ethanol extract of Artocarpus heterophyllus stem bark on pancreatic beta-cell dysfunction in alloxan-induced diabetic rats. J Evid Based Complement Altern Med. 2017;22:538-43. https://doi.org/10.1177/ 2156587216685510.

11. Prabha B, Neethu S, Krishnan SL, Sherin DR, Madhukrishnan M, Ananthakrishnan R, Rameshkumar KB, Manojkumar TK, Jayamurthy P, Radhakrishnan KV. Antidiabetic potential of phytochemicals isolated from the stem bark of Myristica fatua Houtt. var. magnifica (Bedd.) Sinclair. Bioorg Med Chem. 2018;26:3461-7. https://doi.org/10.1016/j.bmc.2018.05.020.

12. Mouho DG, Oliveira AP, Kodjo CG, Valentao P, Gil-Izquierdo A, Andrade PB, Ouattara ZA, Bekro YA, Ferreres F. Chemical findings and in vitro biological studies to uphold the use of Ficus exasperata Vahl leaf and stem bark. Food Chem Toxicol. 2018;112:134-44. https://doi.org/10.1016/j.fct.2017.12.043.

13. Kumar B, Vijayakumar M, Govindarajan R, Pushpangadan P. Ethnopharmacological approaches to wound healing--exploring medicinal plants of India. J Ethnopharmacol. 2007;114:103-13. https://doi.org/10.1016/ j.jep.2007.08.010.

14. Bueno FG, Panizzon GP, de Leite Mello EVS, Lechtenberg M, Petereit F, de Mello JCP, Hensel A. Hydrolyzable tannins from hydroalcoholic extract from Poincianella pluviosa stem bark and its wound-healing properties: phytochemical investigations and influence on in vitro cell physiology of human keratinocytes and dermal fibroblasts. Fitoterapia. 2014;99:252-60. https://doi.org/10.1016/j.fitote.2014.10.007

15. Bueno FG, Moreira EA, Morais GR, Pacheco IA, Baesso ML, Leite-Mello EV, Mello JC. Enhanced cutaneous wound healing in vivo by standardized crude extract of Poincianella pluviosa. PLoS One. 2016;11:e0149223. https:// doi.org/10.1371/journal.pone.0149223.

16. Bourdy G, DeWalt SJ, Chavez de Michel LR, Roca A, Deharo E, Munoz V, Balderrama L, Quenevo C, Gimenez A. Medicinal plants uses of the Tacana, an Amazonian Bolivian ethnic group. J Ethnopharmacol. 2000;70:87-109. https://doi.org/10.1016/s0378-8741(99)00158-0.

17. Kayano AC, Lopes SC, Bueno FG, Cabral EC, Souza-Neiras WC, Yamauchi LM, Foglio MA, Eberlin MN, Mello JC, Costa FT. In vitro and in vivo assessment of the anti-malarial activity of Caesalpinia pluviosa. Malar J. 2011;10:112. https:// doi.org/10.1186/1475-2875-10-112.

18. de Souza JE, do Nascimento MFA, Borsodi MPG, de Almeida AP, RossiBergmann B, de Oliveira AB, Costa SS. Leaves from the tree Poincianella pluviosa as a renewable source of antiplasmodial compounds against chloroquine-resistant Plasmodium falciparum. J Braz Chem Soc. 2018;29: 1318-27. https://doi.org/10.21577/0103-5053.20170228.

19. Singleton VL, Rossi JA. Colorimetry of total phenolics with phosphomolybdic-phosphotungstic acid reagents. Am J Enol Vitic. 1965;16: 144-58 https://www.ajevonline.org/content/16/3/144.short.

20. Alothman M, Bhat R, Karim AA. Antioxidant capacity and phenolic content of selected tropical fruits from Malaysia, extracted with different solvents Food Chem. 2009;115:785-8. https://doi.org/10.1016/j.foodchem.2008.12.005.

21. Correa VG, Goncalves GA, de Sa-Nakanishi AB, Ferreira I, Barros L, Dias MI, Koehnlein EA, de Souza CGM, Bracht A, Peralta RM. Effects of in vitro digestion and in vitro colonic fermentation on stability and functional properties of yerba mate (Ilex paraguariensis a. St. Hil.) beverages. Food Chem. 2017;237:453-60. https://doi.org/10.1016/j.foodchem.2017.05.125.

22. Miller GL. Use of dinitrosalicylic acid reagent for determination of reducing sugar. Anal Chem. 1959;31:426-8. https://doi.org/10.1021/ac60147a030.

23. Larson SB, Day JS, McPherson A. X-ray crystallographic analyses of pig pancreatic alpha-amylase with limit dextrin, oligosaccharide, and alpha-cyclodextrin. Biochemistry. 2010;49:3101-15. https://doi.org/10.1021/bi902183w

24. Phillips JC, Braun R, Wang W, Gumbart J, Tajkhorshid E, Villa E, Chipot C, Skeel RD, Kale L, Schulten K. Scalable molecular dynamics with NAMD. J Comput Chem. 2005;26:1781-802. https://doi.org/10.1002/jcc.20289.

25. Mackerell AD Jr, Feig M, Brooks CL 3rd. Extending the treatment of backbone energetics in protein force fields: limitations of gas-phase quantum mechanics in reproducing protein conformational distributions in molecular dynamics simulations. J Comput Chem. 2004;25:1400-15. https:// doi.org/10.1002/jcc.20065.

26. Morris GM, Huey R, Lindstrom W, Sanner MF, Belew RK, Goodsell DS, Olson AJ. AutoDock4 and AutoDockTools4: automated docking with selective receptor flexibility. J Comput Chem. 2009;30:2785-91. https://doi.org/10. 1002/jcc.21256

27. Dallakyan S, Olson AJ. Small-molecule library screening by docking with PyRx. Methods Mol Biol. 2015;1263:243-50. https://doi.org/10.1007/978-14939-2269-7_19.

28. Antonelli-Ushirobira TM, Blainski A, Fernandes HG, Moura-Costa GF, Costa MA, Campos-Shimada LB, Salgueiro-Pagadigorria CL, Kaneshima EN, Becker TC, Leite-Mello EV, Mello JC. Acute toxicity and long-term safety evaluation of the crude extract from rhizomes of Limonium brasiliense in mice and rats. J Ethnopharmacol. 2015;174:293-8. https://doi.org/10.1016/j.jep.2015.08.022.

29. Brazil, Gesef. Guia para a condução de estudos não clínicos de toxicologia e segurança farmacológica necessários ao desenvolvimento de medicamentos, (2013). http://portal.anvisa.gov.br/documents/33836/24 92465/Guia+para+a+Condu\%C3\%A7\%C3\%A30+de+Estudos+N\%C3\%A3o+ Cl\%C3\%ADnicos+de+Toxicologia+e+Seguran\%C3\%A7a+Farmacol\%C3\%B3 gica+Necess\%C3\%A1rios+ao+Desenvolvimento+de+Medicamentos+-Vers\%C3\%A3o+2/a8cad67c-14c8-4722-bfof-058a3a284f75.

30. Chambi F, Chirinos R, Pedreschi R, Betalleluz-Pallardel I, Debaste F, Campos D. Antioxidant potential of hydrolyzed polyphenolic extracts from tara (Caesalpinia spinosa) pods. Ind Crop Prod. 2013;47:168-75. https://doi.org/ 10.1016/j.indcrop.2013.03.009.

31. Pawar C, Surana S. Antioxidant properties of the methanol extract of the wood and pericarp of Caesalpinia decapetala. J Young Pharm. 2010;2:45-9. https://doi.org/10.4103/0975-1483.62212.

32. Shukla S, Mehta A, John J, Singh S, Mehta P, Vyas SP. Antioxidant activity and total phenolic content of ethanolic extract of Caesalpinia bonducella seeds. Food Chem Toxicol. 2009;47:1848-51. https://doi.org/10.1016/j.fct. 2009.04.040.

33. Oboh G, Ogunsuyi OB, Ogunbadejo MD, Adefegha SA. Influence of gallic acid on alpha-amylase and alpha-glucosidase inhibitory properties of acarbose. J Food Drug Anal. 2016;24:627-34. https://doi.org/10.1016/j.jfda. 2016.03.003.

34. Kumar S, Narwal S, Kumar V, Prakash O. a-glucosidase inhibitors from plants: A natural approach to treat diabetes. Pharmacogn Rev. 2011;5:19. https:// doi.org/10.4103/0973-7847.79096.

35. Gupta N, Gupta S, Mahmood A. Gallic acid inhibits brush border disaccharidases in mammalian intestine. Nutr Res. 2007;27:230-5. https://doi. org/10.1016/j.nutres.2007.02.001.

36. Vasconcelos CF, Maranhao HM, Batista TM, Carneiro EM, Ferreira F, Costa J, Soares LA, Sa MD, Souza TP, Wanderley AG. Hypoglycaemic activity and molecular mechanisms of Caesalpinia ferrea Martius bark extract on streptozotocin-induced diabetes in Wistar rats. J Ethnopharmacol. 2011;137: 1533-41. https://doi.org/10.1016/j.jep.2011.08.059.

37. Hassan SK, El-Sammad NM, Mousa AM, Mohammed MH, Farrag A e RH, Hashim ANE, Werner V, Lindequist U, Nawwar MAE-M. Hypoglycemic and antioxidant activities of Caesalpinia ferrea Martius leaf extract in streptozotocin-induced diabetic rats. Asian Pac J Trop Biomed. 2015;5:46271. https://doi.org/10.1016/j.apjtb.2015.03.004.

38. Kato-Schwartz CG, Bracht F, de Almeida Gonçalves G, Soares AA, Vieira TF, Brugnari T, Bracht A, Peralta RM. Inhibition of a-amylases by pentagalloyl glucose: kinetics, molecular dynamics and consequences for starch absorption. J Funct Foods. 2018;44:265-73. https://doi.org/10.1016/j.jff.2018.03.025.

39. da Silva AP, Oliveira GL, Medeiros SC, Sousa AM, Lopes Lda S, David JM, da Costa Junior JS, de Freitas RM. Pre-clinical toxicology of garcinielliptone FC, a tautomeric pair of polyprenylated benzophenone, isolated from Platonia insignis Mart seeds. Phytomedicine. 2016;23:477-82. https://doi.org/10.1016/ j.phymed.2016.02.013.

40. Li WL, Zheng HC, Bukuku J, de Kimpe N. Natural medicines used in the traditional Chinese medical system for therapy of diabetes mellitus. J Ethnopharmacol. 2004;92:1-21. https://doi.org/10.1016/j.jep.2003.12.031.

41. Chen J, Mangelinckx S, Adams A, Wang Z, Li W, Kimpe N. Natural flavonoids as potential herbal medication for the treatment of diabetes mellitus and its complications. Nat Prod Commun. 2015;10:187-200. https://doi.org/10.1177/ 1934578X1501000140.

42. Harlev E, Nevo E, Mirsky N, Ofir R. Antidiabetic attributes of desert and steppic plants: a review. Planta Med. 2013;79:425-36. https://doi.org/10. 1055/s-0032-1328331.

43. Palanisamy UD, Ling LT, Manaharan T, Appleton D. Rapid isolation of geraniin from Nephelium lappaceum rind waste and its anti-hyperglycemic activity. Food Chem. 2011;127:21-7. https://doi.org/10.1016/j.foodchem. 2010.12.070. 
44. H.S. Cheng, S.H. Ton, K.A. Kadir, Ellagitannin geraniin: a review of the natural sources, biosynthesis, pharmacokinetics and biological effects. Phytochem Rev 2017;16:159-193. doi: https://doi.org/10.1007/s11101-016-9464-2.

45. Gunawan-Puteri MD, Kato E, Kawabata J. Alpha-amylase inhibitors from an Indonesian medicinal herb, Phyllanthus urinaria. J Sci Food Agric. 2012;92: 606-9. https://doi.org/10.1002/jsfa.4615.

\section{Publisher's Note}

Springer Nature remains neutral with regard to jurisdictional claims in published maps and institutional affiliations.

Submit your manuscript to a SpringerOpen ${ }^{\circ}$ journal and benefit from:

- Convenient online submission

- Rigorous peer review

- Open access: articles freely available online

- High visibility within the field

- Retaining the copyright to your article

Submit your next manuscript at $\boldsymbol{\sim}$ springeropen.com 